IZA DP No. 9244

Tempora mutantur, nos et mutamur in illis:

Religion and Female Employment over Time

Justina A.V. Fischer

Francesco Pastore

July 2015 


\title{
Tempora mutantur, nos et mutamur in illis: Religion and Female Employment over Time
}

\author{
Justina A.V. Fischer \\ University of Mannheim \\ Francesco Pastore \\ Seconda Università di Napoli \\ and IZA
}

Discussion Paper No. 9244 July 2015

IZA

\author{
P.O. Box 7240 \\ 53072 Bonn \\ Germany
}

\author{
Phone: +49-228-3894-0 \\ Fax: +49-228-3894-180 \\ E-mail: iza@iza.org
}

\begin{abstract}
Any opinions expressed here are those of the author(s) and not those of IZA. Research published in this series may include views on policy, but the institute itself takes no institutional policy positions. The IZA research network is committed to the IZA Guiding Principles of Research Integrity.

The Institute for the Study of Labor (IZA) in Bonn is a local and virtual international research center and a place of communication between science, politics and business. IZA is an independent nonprofit organization supported by Deutsche Post Foundation. The center is associated with the University of Bonn and offers a stimulating research environment through its international network, workshops and conferences, data service, project support, research visits and doctoral program. IZA engages in (i) original and internationally competitive research in all fields of labor economics, (ii) development of policy concepts, and (iii) dissemination of research results and concepts to the interested public.
\end{abstract}

IZA Discussion Papers often represent preliminary work and are circulated to encourage discussion. Citation of such a paper should account for its provisional character. A revised version may be available directly from the author. 
IZA Discussion Paper No. 9244

July 2015

\section{ABSTRACT}

\section{Tempora mutantur, nos et mutamur in illis: Religion and Female Employment over Time}

This study analyses whether the role of religion for employment of married women in Europe has changed over time and along women's life cycles. Using information on 44'000 married European women from the World Values Survey 1981-2013, we find that in OECD-Europe there is little difference among women of any age since 1997. For non-OECD-Europe, we find differences by religion among young women, but not among those older than 40 years, which we attribute to an upbringing under communist regimes. Only Muslim women show a lower employment probability that persists across time, regions, and life cycles.

JEL Classification: D83, J16, J22, N34, Z12, Z13

Keywords: religion, labor market participation, modernization, gender, Europe, transition countries, Eastern Europe, OECD, World Values Survey

Corresponding author:

Justina A.V. Fischer

Department of Economics

University of Mannheim

L7,3.5

68131 Mannheim

Germany

E-mail: mail@justinaavfischer.de 


\section{Introduction}

Tempora mutantur, nos et mutamur in illis (John Owen) - the times are changing and we also change with them. While many empirical studies have shown that religion and its inherent traditional role model affect female labor market participation, such influence may well change as time passes by, as society and economy transform. Fernandez (2013) shows for the USA over a time span of 120 years that a revision of conservative values causes higher female employment rates. We argue that also the relative importance of household duties restricting labor market access might change with time and over the life cycle.

Previous studies on the role of religious denominations for female employment have revealed that conservative values conveyed through religion are important factors (e.g. Lehrer 1995, H’madoun, 2010). Pastore and Tenaglia (2015) report for the 2008 wave of the European Values Survey a lower likelihood of employment for Catholic, Christian-Orthodox and Muslim women compared to their Protestant peers. However, the recent study by Heineck (2004) reveals for Germany with a population roughly split in half between Catholics and Protestants no behavioral difference by religion.

This article investigates whether religion affects labor market participation of married women in Europe in a persistent manner, or whether such influence evolves over time, differently in OECD and non-OECD member states.

\section{Data and Methodology}

This study employs the World Values Survey (WVS) 1981-2013 that since 1981 has been conducted about every 5 years in more than 80 countries worldwide; with about 1'000 interviewees per country, the WVS gives rise to a repeated cross-section with a panel structure at the country level. We exploit this country panel structure to control for unobservable country characteristics, worldwide economic shocks, and changes in national institutions over time. The WVS covers a time span of about 20 years for Eastern Europe but 30 years for Western Europe - allowing to investigate the development of religion effects over time. 
The WVS also includes a set of socio-demographic characteristics such as sex, age, marital status, number of children, education, and occupational status. Religious denominations include Catholicism, Protestantism, Christian-Orthodoxy, Judaism, Islam, Free Church Associations (Evangelicals), Buddhism, Hinduism, 'no denomination' and Atheism. We exclude Buddhists and Hindus from the sample (around 20 observations each) and women with 'other denominations' (around 450 observations); women with 'no denomination' and 'Atheists' jointly form the reference group. For reasons of economic theory of choice under restrictions, but also for reasons of reverse causality, we restrict the regression sample to married and cohabiting women aged between 25 and 60 years (see also Heineck, 2004). Our final sample includes about 44'000 women in more than 40 European countries. Table 1 presents descriptive statistics.

Table 1: Descriptive Statistics, WVS, Europe, 1981-2013, 44’069 married women

\begin{tabular}{|c|c|c|c|c|}
\hline Variable & Mean & Std. Dev. & Min & Max \\
\hline Employed & .62 & .48 & 0 & 1 \\
\hline Active & .68 & .47 & 0 & 1 \\
\hline No denomination/Atheist & (ref.cat.) & & & \\
\hline Catholic & .35 & .48 & 0 & 1 \\
\hline Protestant & .14 & .34 & 0 & 1 \\
\hline Muslim & .03 & .17 & 0 & 1 \\
\hline Orthodox & .19 & .39 & 0 & 1 \\
\hline Jewish & .001 & .03 & 0 & 1 \\
\hline Free Church & .03 & .16 & 0 & 1 \\
\hline Atheist & .26 & .44 & 0 & 1 \\
\hline Age & 41.91 & 9.79 & 18 & 60 \\
\hline \multicolumn{5}{|l|}{ Number of children } \\
\hline 0 & (ref.cat.) & & & \\
\hline 1 & .22 & .41 & 0 & 1 \\
\hline 2 & .44 & .49 & 0 & 1 \\
\hline 3 & .16 & .37 & 0 & 1 \\
\hline 4 & .05 & .22 & 0 & 1 \\
\hline 5 & .02 & .13 & 0 & 1 \\
\hline 6 & .01 & .09 & 0 & 1 \\
\hline 7 & .002 & .05 & 0 & 1 \\
\hline 8 & .002 & .05 & 0 & 1 \\
\hline No info on children & .03 & .16 & 0 & 1 \\
\hline \multicolumn{5}{|l|}{ Education } \\
\hline Elementary & .47 & .49 & 0 & 1 \\
\hline Secondary & (ref.cat.) & & & \\
\hline Tertiary & .17 & .37 & 0 & 1 \\
\hline Year & 1996.87 & 7.96 & 1981 & 2013 \\
\hline OECD & .59 & .49 & 0 & 1 \\
\hline
\end{tabular}


We estimate the probability of being employed ( $\mathrm{Y}_{\text {ist }}=$ employed $)$ of wife i living in country s at year $t$ as a function of her religious denomination religion ist: $_{\text {: }}$

$\operatorname{Prob}\left(\mathrm{Y}_{\text {ist }}=\right.$ employed $)=\alpha$ religion $_{\text {ist }}+\beta^{\prime} \mathrm{X}_{\text {ist }}+\mathrm{FE}_{\mathrm{s}}+\mathrm{FE}_{\mathrm{t}}+\mathrm{FE}_{\mathrm{s}} \mathrm{x} \mathrm{FE}_{\mathrm{t}}+\varepsilon_{\text {ist }}$

where $\mathrm{Y}_{\text {ist }}$ denotes the employment status. A vector of personal characteristics $\left(\mathrm{X}_{\mathrm{ist}}\right)$ such as age, age squared, number of children and education and an idiosyncratic error term complete the model. A set of country and time fixed effects $\left(\mathrm{FE}_{\mathrm{s}}+\mathrm{FE}_{\mathrm{t}}\right)$ and their interactions $\left(\mathrm{FE}_{\mathrm{s}} \mathrm{x} \mathrm{FE}_{\mathrm{t}}\right)$ and an idiosyncratic error term complete our model. Standard errors are estimated with observations clustered at the country level to account for heteroskedasticity and within-country serial correlation.

\section{Findings}

Table 2 tests the persistence of religion effects for female labor market participation over time, by splitting the data into a 1981-1996 period and a post-transition 19972013 period, roughly halving the sample (columns 3 through 5). As robustness test, column 2 presents estimates for the 1981-1990 period, while column 1 reports estimates for the full WVS sample of about 44’000 women in Europe 1981-2013.

Behavioral patterns of women have been shown to differ between Western and Eastern Europe, defined by the Hapsburg empire borders (Fischer and Aydiner-Asnar, 2015). For this reason Table 2 splits the post-1996 sample into two groups: OECD and non-OECD member states within Europe, where membership in OECD reflects economic openness, democratization, and other forms of societal modernization (columns 4 and 5). ${ }^{1}$ The focus of our discussion is on Catholics, Protestants, Christian-Orthodox and Muslims.

\footnotetext{
${ }^{1}$ Membership in OECD is as of 2000. A simple geographic split into Eastern and Western Europe produces similar results except for the difference between Catholics and Protestants in column 5 the significance of which vanishes.
} 
The full sample estimates in column 1 support the finding of the previous literature that Catholic, Christian-Orthodox, and Muslim women are less likely to be employed than Protestants (e.g. Pastore and Tenaglia, 2013).

Table 2 shows clearly that, in OECD-Europe, the importance of religion for female employment vanishes over time, as the comparison across time periods 19811990/1996 and 1997-2013 reveals (columns 2, 3, and 4). Put differently, the behavior of married women with all sorts of denominations appears to have converged over time when it comes to labor market participation. The only exception pertains to Muslim women who keep abstaining from employment (column 4).

Table 2: Religion and female employment over time in Europe

\begin{tabular}{|c|c|c|c|c|c|}
\hline & $(1)$ & $(2)$ & (3) & (4) & (5) \\
\hline & 1981-2013 & $1981-1990$ & 1981-1996 & $1997-2013$ & $1997-2013$ \\
\hline & Full sample & $\begin{array}{l}\text { Western } \\
\text { Europe }\end{array}$ & & OECD & Non-OECD \\
\hline \multirow[t]{2}{*}{ Catholic } & $-0.258 * *$ & $-0.351 *$ & $-0.420 * *$ & -0.0333 & $-0.351^{* *}$ \\
\hline & [0.0539] & {$[0.146]$} & [0.0921] & {$[0.0636]$} & [0.115] \\
\hline \multirow[t]{2}{*}{ Protestant } & -0.150 & -0.182 & -0.327 & 0.0217 & -0.0535 \\
\hline & {$[0.130]$} & {$[0.215]$} & {$[0.242]$} & {$[0.0751]$} & {$[0.110]$} \\
\hline \multirow[t]{2}{*}{ Muslim } & $-0.879 * *$ & $-2.109 *$ & $-0.911^{* *}$ & $-1.228 * *$ & $-0.761^{* *}$ \\
\hline & {$[0.167]$} & {$[1.020]$} & {$[0.245]$} & {$[0.301]$} & {$[0.208]$} \\
\hline \multirow{2}{*}{ Orthodox } & $-0.189 * *$ & & -0.219 & -0.331 & -0.166 \\
\hline & {$[0.0635]$} & & {$[0.147]$} & {$[0.244]$} & [0.0883] \\
\hline \multirow[t]{2}{*}{ Jewish } & -0.655 & -1.122 & -0.817 & -0.743 & -0.352 \\
\hline & {$[0.378]$} & {$[0.838]$} & {$[0.756]$} & {$[0.520]$} & {$[0.616]$} \\
\hline \multirow[t]{2}{*}{ Free Church } & $-0.228 *$ & -0.170 & $-0.562 *$ & -0.0485 & -0.0681 \\
\hline & [0.109] & {$[0.245]$} & [0.218] & {$[0.151]$} & {$[0.322]$} \\
\hline micro vars & yes & yes & yes & yes & yes \\
\hline country FE & yes & yes & yes & yes & yes \\
\hline time FE & yes & yes & yes & yes & yes \\
\hline $\begin{array}{l}\text { interacted } \\
\text { fixed effects }\end{array}$ & yes & yes & yes & yes & yes \\
\hline Observations & 44’069 & 4’396 & 20’068 & 12'131 & $11^{\prime} 870$ \\
\hline Countries & 41 & 15 & 33 & 22 & 19 \\
\hline Pseudo R2 & 0.179 & 0.168 & 0.205 & 0.139 & 0.182 \\
\hline
\end{tabular}

Notes: Logit estimations with the WVS, 1981-2013, married or cohabiting women in Europe, between the age 25 and 60 years. Dependent variable is employment (binary), where ' 1 ' indicates 'employed full-time, part-time, or self-employed', and '0' 'not-employed (early retired, unemployed, housewife)'. Disabled women and female students have been excluded. The set of individual controlling variables include age, age squared, number of children, and educational attainment. All models include country and time fixed effects and their interactions. Squared brackets report robust standard errors obtained through clustering at the country level; ${ }^{* *} \mathrm{p}<0.01,{ }^{*} \mathrm{p}<0.05$. 
In non-OECD-Europe, however, a differential behavior between Catholic and Protestant women persists until today, which might be caused by lagging modernization processes (column 5). Unfortunately, the WVS does not provide information during the communist era, prior to 1991. Muslim women are, again, less likely to be in gainful employment.

Table 3 tests the presence of life cycle effects of religion for female employment: we estimate the model for two subsamples of women, those aged 25-39 years and those aged 40-60 years, and, again, test differential effects across time periods (1981-1996 and 1997-2013).

In OECD-Europe, prior to 1996, both older and younger married Catholics appear equally conservative in behavior: both show a lower likelihood of being employed compared to Protestants. After 1996, this picture changes: there is convergence in behavior and irrelevance of religion in either age group.

In non-OECD-Europe, surprisingly, younger married Christian-Orthodox or Catholic women appear now more influenced by their religion than married women aged 40 to 60 years. There are two possible explanations: for younger wives, the restriction of child care might be more binding. Alternatively, there might be a secular communism effect and path dependency in the older age group. The negative effect of the Christian-Orthodox denomination in the 1981-1996 sample for older wives (combined with the insignificance for the younger ones) confirms the communism effectinterpretation.

In contrast, married Muslim women in Europe, across all regions and age groups, show the identical labor market-abstaining behavior. 
Table 3: Religion and female employment across age groups in Europe

\begin{tabular}{|c|c|c|c|c|c|c|}
\hline & $(1)$ & (2) & (3) & (4) & (5) & (6) \\
\hline & 1981-1996 & 1981-1996 & $1997-2013$ & $1997-2013$ & $1997-2013$ & 1997-2013 \\
\hline & age $<40$ & age $>39$ & age $<40$ & age $>39$ & age $<40$ & age $>39$ \\
\hline & & & OECD & OECD & $\begin{array}{c}\text { Non- } \\
\text { OECD }\end{array}$ & $\begin{array}{l}\text { Non- } \\
\text { OECD }\end{array}$ \\
\hline \multirow[t]{2}{*}{ Catholic } & $-0.297 * *$ & $-0.548^{* *}$ & -0.103 & 0.0038 & $-0.587 * *$ & -0.190 \\
\hline & [0.0954] & [0.118] & [0.134] & {$[0.0760]$} & [0.149] & {$[0.146]$} \\
\hline \multirow[t]{2}{*}{ Protestant } & -0.417 & -0.314 & -0.0194 & 0.0427 & -0.232 & 0.141 \\
\hline & {$[0.234]$} & {$[0.260]$} & {$[0.0913]$} & {$[0.0928]$} & {$[0.213]$} & {$[0.255]$} \\
\hline \multirow[t]{2}{*}{ Muslim } & $-0.963 * *$ & $-1.092 * *$ & $-0.936 * *$ & $-1.486 * *$ & $-0.834^{* *}$ & $-0.790 * *$ \\
\hline & {$[0.306]$} & {$[0.276]$} & {$[0.338]$} & {$[0.236]$} & {$[0.268]$} & {$[0.214]$} \\
\hline \multirow{2}{*}{ Orthodox } & 0.0205 & $-0.441^{*}$ & -0.249 & -0.342 & $-0.339 * *$ & -0.0460 \\
\hline & [0.168] & {$[0.196]$} & [0.315] & [0.345] & [0.104] & [0.122] \\
\hline \multirow[t]{2}{*}{ Jewish } & -0.889 & -0.466 & -1.248 & -0.628 & -0.165 & -0.254 \\
\hline & {$[0.856]$} & {$[0.906]$} & [0.659] & {$[0.576]$} & [1.013] & {$[0.804]$} \\
\hline \multirow[t]{2}{*}{ Free Church } & $-0.491 *$ & $-0.654^{*}$ & -0.174 & 0.0150 & -0.156 & -0.196 \\
\hline & {$[0.250]$} & {$[0.309]$} & {$[0.135]$} & [0.273] & [0.275] & {$[0.524]$} \\
\hline micro vars & yes & Yes & yes & yes & yes & Yes \\
\hline country FE & yes & Yes & yes & yes & yes & Yes \\
\hline time FE & yes & Yes & yes & yes & yes & Yes \\
\hline $\begin{array}{l}\text { interacted fixed } \\
\text { effects }\end{array}$ & yes & Yes & yes & yes & yes & yes \\
\hline Observations & 9'239 & 10 '823 & 4’911 & 7’220 & 5’076 & 6’789 \\
\hline Countries & 33 & 33 & 22 & 22 & 19 & 19 \\
\hline Pseudo R2 & 0.182 & 0.239 & 0.104 & 0.181 & 0.161 & 0.221 \\
\hline
\end{tabular}

Notes: see Table 2.

\section{Conclusion}

Our study is the first to analyze whether the impact of religion on female employment in Europe differs a) by time period, b) over the life cycle, and c) cultural regions.

In European OECD member states the impact of religious denomination for married women is not persistent, but vanishes over time: Using the World Values Survey 1981-2013 we detect in the early years of the survey (1981-1996) behavioral differences by religion, that in the more recent years (1997-2013) have disappeared, for both young and old wives likewise (except for Muslim wives). Possibly, membership in OECD promotes modernization processes.

In non-OECD-Europe, however, even after 1996, religion determines labor market participation of married women. This effect appears to be driven by women younger than 40 years, while older women show now behavioral differences across religions 
(except for Muslims). A possible explanation is the upbringing under the communist regimes that promoted female labor market participation and combatted religious values for ideological reasons.

Only Muslim women are less likely to be gainfully employed, across all time periods, in both regions, across all life years. This finding corroborates previous studies (e.g. Hayo and Caris, 2013).

In conclusion, cultural differences within Europe can possibly explain contradictory findings of various preceding studies. In a broader perspective, our analysis suggests that the impact of religion on female employment changes with a country's history and institutions. 


\section{References}

Fernandez R. (2013), Cultural Change as Learning: The Evolution of Female Labor Force Participation over a Century, American Economic Review, 103(1), 472-500.

Fischer, J.A.V., \& N. Aydıner-Avsar (2015), Are women in the MENA region really that different from women in Europe? Globalization, conservative values and female labor market participation, MPRA paper no. 63800, forthcoming.

H'madoun, M. (2010), Religion and labor force participation of women, University of Antwerp, Department of Applied Economics, Research Paper 2010-007.

Hayo, B., \& Caris, T. (2013), Female Labour Force Participation in the MENA Region: The Role of Identity, Review of Middle East Economics and Finance, 9(3), 271-292.

Heineck, G. (2004), Does religion influence the labor supply of married women in Germany?, Journal of Socio-Economics, 33, 307-328.

Lehrer, E. (1995), The Effects of Religion on the Labor Supply of Married Women, Social Science Research, 24, 281-301.

Pastore, F., \& Tenaglia, S. (2013), Ora et non Labora? A Test of the Impact of Religion on Female Labor Supply, IZA DP No. 7356. 